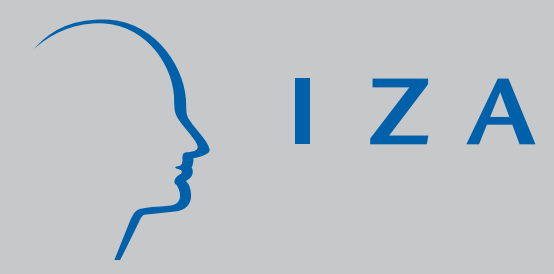

IZA DP No. 1377

Evidence on Training and Career Paths: Human Capital, Information and Incentives

Eduardo Melero

November 2004 


\title{
Evidence on Training and Career Paths: Human Capital, Information and Incentives
}

\author{
Eduardo Melero \\ Universitat Pompeu Fabra \\ and IZA Bonn
}

Discussion Paper No. 1377

November 2004

\author{
IZA \\ P.O. Box 7240 \\ 53072 Bonn \\ Germany \\ Phone: +49-228-3894-0 \\ Fax: +49-228-3894-180 \\ Email: iza@iza.org
}

Any opinions expressed here are those of the author(s) and not those of the institute. Research disseminated by IZA may include views on policy, but the institute itself takes no institutional policy positions.

The Institute for the Study of Labor (IZA) in Bonn is a local and virtual international research center and a place of communication between science, politics and business. IZA is an independent nonprofit company supported by Deutsche Post World Net. The center is associated with the University of Bonn and offers a stimulating research environment through its research networks, research support, and visitors and doctoral programs. IZA engages in (i) original and internationally competitive research in all fields of labor economics, (ii) development of policy concepts, and (iii) dissemination of research results and concepts to the interested public.

IZA Discussion Papers often represent preliminary work and are circulated to encourage discussion. Citation of such a paper should account for its provisional character. A revised version may be available directly from the author. 


\title{
ABSTRACT
}

\section{Evidence on Training and Career Paths: Human Capital, Information and Incentives}

In this paper, I analyse the relationship between job-related training and career progress of workers. Most theories of career paths and task assignment rely on human capital accumulation. Therefore, it seems natural to start assessing the empirical validity of such theories by analysing the effect of training on the career progress of an individual. I use the sample of workers from twelve waves of the BHPS (1991-2002) to study the impact of training over the probability of making a career-improving move, using both between-groups and within-group panel data estimators. I find that job-related training received by female workers boosts significantly their chances of being promoted in the next future, while leaving virtually unaffected the chances of male workers. Then, I investigate how do training and promotion jointly influence wage growth. The results show that their interaction is, if any, positive. Additional evidence confirms that the career path of female workers seem to be importantly affected by the market value of their human capital, while that of men might be more affected by the role of promotion systems as mechanisms devised to provide incentives.

JEL Classification: M51, M52, M53, J24, J64

Keywords: human capital, training, task allocation, careers, internal labour markets

\author{
Eduardo Melero \\ Department of Business and Economics \\ Universitat Pompeu Fabra \\ C/ Ramon Trias Fargas 25-27 \\ Barcelona 08005 \\ Spain \\ Email: eduardo.melero@upf.edu
}




\section{$\underline{\text { Introduction }}$}

A large part of the literature concerning task assignment and career paths recognises the important role of human capital accumulation. Nevertheless, little empirical research has been done regarding the effect of job related training provided to workers on their career progress. In this paper I deal explicitly with this issue and use the resulting evidence to evaluate how the different theoretical frameworks fit the labour market reality and, more importantly, to show how different are the driving forces behind the career paths of male and female workers.

Promotion systems may be institutions used by firms to provide incentives to lower level workers to exert effort at their jobs. However, if such effort includes learning firm-specific skills or if the promotion decision is motivated by a better allocation of talents, any jobrelated training carried out by the worker should have a role in the promotion decision. The in-depth analysis of the influence of job-related training on subsequent career progress and the joint effect of training and promotion on wages is then useful to disentangle which of the different views of promotions suits better to the reality of male and female workers in the labour market.

The only empirical work published to date that included training as a determinant of promotion receipt is Pergamit and Veum (1999) who used the 1989 and 1990 samples from the American National Longitudinal Survey of Youth (NLSY) to analyse the causes and consequences of promotion, including training among the variables of interest. Their study of the relationship, however, only includes cross-sectional estimators, since the specific questions about job changes were not part of the longitudinal questionnaire. Other studies that analyse the determinants and consequences of promotions are McCue (1996) using the American Panel Study of Income Dynamics (PSID) for period 1976-1988 and Francesconi (2001) using the British Household Panel Survey (BHPS) for the 1991-1995 waves. All of them use (continuous and discrete-time) random effects probability models to give a description of what type of workers are more likely to obtain promotions. Sicherman and Galor (1990) also used data from the 1976-1981 waves of the PSID to analyse determinants 
of within-firm and between-firms career moves. Consistently with their model, they found that workers whose estimated probability of promotion was high but did not get the promotion were more likely to leave their firm.

Most of the relevant detailed evidence regarding career paths, however, comes from single firm evidence ${ }^{\square}$. Indeed, some papers like Medoff and Abraham (1980) and, especially, Baker Gibbs and Holmstrom (1994) stated the following stylised facts about task assignment and careers: $(i)$ high correlation between measured worker's productivity and promotion prospects (ii) (partial) attachment of wage growth to promotions, (iii) serial correlation of wage increases and promotions, (iv) existence of fast tracks and (v) extremely low frequency of demotions. The subsequent building of theoretical models of careers in organisations, which will be summarised in the next section, have been largely conditioned by these results.

In this paper, I use twelve waves from the BHPS (1991-2002) to investigate specifically how job-related training affects the chances that a worker has of obtaining a career improvement, either in the form of a promotion or a quit for a better job, and how training and promotion interact in boosting wage growth. The first question is essential to evaluate to what extent training provides workers non-pecuniary rewards in the form of higher probabilities of a position upgrade $\mathrm{e}^{3}$. The second issue is important in order to distinguish which part of a wage increase is due to training and which to promotion when they happen together and to what extent they complement each other. Overall, analysing both questions provides a framework to investigate how different are the shapes of career paths of men and women and, secondly, to make an assessment of which the existent theories on human capital accumulation and task assignment fits better the reality of career paths in British firms.

\footnotetext{
${ }^{1}$ See report by Gibbons and Waldman (1999a)

${ }^{2}$ The definition of fast tracks is basically this: Workers that have been promoted more quickly to a given level in the hierarchy of a firm tend to be promoted more quickly than the rest to the next level.

${ }^{3}$ Francesconi (2001) reported significant increases in job satisfaction reported by workers, which not only affected to "satisfaction with pay", but also to "satisfaction with job itself".
} 
The contribution of the results obtained in this work is twofold. On the one hand, the presented evidence shows what empirical shortcomings have each of the set of theories analysed here and the extent to what each of them can be overcome. More interestingly, important differences between male and female workers are found in the way that training affects career moves and in the way that training and promotion affect wage growth. This suggests that sex differences in career paths and earnings should not be explained in terms of a single theory. Rather, the careers of men and women seem to fit in different theoretical paradigms.

The paper is organised as follows. In the next section, I summarise and broadly classify the different theories dealing with career dynamics in organisations, stressing the point on the role that is expected to play a change in workers' human capital through job-related training. Such predictions are then evaluated empirically for male and female workers using the BHPS data. In the third section, this is done generally for both samples of workers. In section fourth, the analysis is done separately for general and specific training, and segregating the samples by age and tenure groups. The last section concludes by giving an overall balance of the results and making some recommendations for further research.

\section{Background}

Theories regarding task assignment and career paths of workers within firms were firstly designed to accommodate some generally observed facts such as the existence of welldefined job ladders and seniority rules usually governing their dynamics. Later theoretical models have also been able to explain more recent findings such as the low frequency of demotions or the existence of fast tracks. Despite the particularities of each contribution to this literature, it is possible to distinguish some "broad" groups of theories that share their main relevant features: $i$ ) theories that rely on human capital accumulation and gradual (symmetric) learning by firms of workers' ability; $i$ ) theories that consider such learning as asymmetric in favour of initial employers and iii) theories that remark the role of promotions as providers of incentives in organisations. These sets of theories, whose main 
predictions are summarised in Appendix A, are briefly described below.

\section{Human Capital and Information}

Promotions may be the natural consequence of the acquisition of skills that are more productive at higher-responsibility jobs. A simple example can illustrate this: let $h_{i t}$ be the amount of skills hold by worker $i$ at period $t$, and $b_{j}+c_{j} h_{i t}$ his/her productivity at job $j$; the potential career of the worker is defined by a number of different jobs, where higher levels are defined by $c_{j+1}>c_{j}$ and $b_{j+1}<b_{j}$, so that a worker is efficiently promoted from job $j$ to job $j+1$ when his/her amount of skills oversteps the threshold $h^{\prime}$ such that $b_{j}+c_{j} h^{\prime}=b_{j+1}+$ $c_{j+l} h$ '. Job-related training would then lead to higher probabilities of promotion as long as it increases $h_{i t}$. The most comprehensive version of this approach is the model by Gibbons and Waldman $(1999,2003)^{4}$. They consider the effective ability of worker $i$ at period $t$, $h_{i t}=\theta_{i} f\left(x_{i t}\right)$, as a complementary combination of individual ability $\theta_{i}$, learned progressively by all potential employers, and the human capital obtained at a decreasing rate through labour experience, $f\left(x_{i t}\right)$. They obtain then a set of predictions that accommodate well Baker et al.'s (1994) findings. Although the authors do not make any explicit reference to jobrelated training, it is straightforward from their model that any increase in the amount of human capital should boost promotion probabilities. Moreover, if the training investment decision is related to a positive update in the belief of the market about worker's ability, the decision itself will be correlated with higher promotion prospects and larger (although not necessarily strongly larger) wage increases.

\section{Asymmetric Information}

A related set of theories has stressed the strategic role of promotions in a setting of private information (Waldman 1984, 1990; Bernhardt 1993, 1995; and, less explicitly, Milgrom

\footnotetext{
${ }^{4}$ There are several previous models inspired by this approach, such as Sattinger (1975) or Rosen (1982). In this paper, I will focus on the Gibbons-Waldman's one because it generalizes and enriches most of them and draws similar predictions.
} 
and Oster, 1987). In terms of the above example, the basic common point of these approaches is that incumbent employers have better information than other potential employers about their workers' ability $\theta_{i}$. This informational advantage allows them to pay tenured workers below their current productivity. In the attempt to preserve such private information, employers fail to promote some workers that would be more productive at higher-level jobs. The result is that promotion rates will be lower than optimal and wages will be mostly attached to job levels, with low within-category variation. As suggested by Bernhardt (1995), the relationship of training and promotion in this setting will be positive as long as the current employer is actively involved in such training and this can be observed by other potential employers. Since the training firm reveals to the market that the worker is able enough to make profitable the investment, part of the wage increase after training will be due to the positive market update of the employee's expected productivity and a subsequent promotion would disclose less information. For the same reason, when training and promotion are observed to occur together, each of their wage returns are expected to be lower than when awarded separately. These asymmetric information-related effects (lower promotion rates, higher correlation between training and promotion, higher returns to training and to promotion with negative interactions) will be more important for those workers whose ability is more uncertain to potential employers; this is likely to be the case of younger workers, immigrants and, less clearly, of racial minorities ${ }^{\mathrm{Z}}$.

\section{Incentives}

Other theories depict "promotion schemes" as contracts designed to provide incentives for (specific) human capital accumulation, rather than its consequence (see Carmichael, 1983; or Prendergast, 1983). Following these models, promotion prospects should depend importantly on seniority, but also on job-related training receipt, as long as it is of a firmspecific kind. Wages should be greatly attached to jobs (and therefore within-firm wage

\footnotetext{
${ }^{5}$ Milgrom and Oster (1987) developed their argument oft the "invisibility hypothesis" in explicit relationship to population minorities. In empirical terms, however, it is very difficult to separate any effect coming from the "invisible" status of minorities from the effect of social and educational conditions.
} 
growth to promotions); furthermore, returns to specific training should depend mostly on promotion achievement.

A related stream of literature presents "promotion systems" as the incentive for workers to work hard (Lazear and Rosen 1981, Chang 1996, Fairburn and Malcomson 2001, Baker, Jensen and Murphy, 1988). Either in the form of the prize of a tournament or an automatic reward to "stayers" in up or out settings, promotions are argued to be the carrot that leads workers to put effort at the workplace. If a promotion were just a nominal change to justify the reward for higher effort, it should be significantly related to indicators of effort such as overtime work, while training or other forms of human capital accumulation would turn out rather irrelevant. The effect of effort on wage growth would depend on the obtaining the position upgrade, while returns to training should be independent of it.

Theories that remark the institutional role of promotions in providing incentives (either to effort or to obtain specific human capital) instead of being a mere question of marketinduced efficient task assignment are strongly related to the internal labour markets approach described by Doeringer and Piore (1971). In organisations with established internal labour markets, jobs are only open to market competition at the lowest levels, while the rest of positions are reserved for promoted employees. Being their job out of the threat of outsiders, promotion prospects are the main sources of incentives for workers within these organisations.

Figuring out which of these theories explains more realistically the actual management of employees' careers may be of special importance in order to explain why similar workers from different population groups have very different labour market outcomes. Theoretical approaches dealing with male/female differences in career evolution and wage growth are usually built upon the assumptions and mechanisms of the type of models described above. By comparing how training and other work-related variables affect promotion chances and wage growth for both genders, we can assess the performance of these different approaches in the general framework of the British labour market. 
The two incentive-oriented views of promotion systems described above are often used to discuss such male/female differentials. Lazear and Rosen (1990), for example, argued that female workers have poorer career prospects because of their higher non-market opportunities that make for them less profitable to exert effort in learning at their tasks in the search of a promotion. Likewise, stronger family commitments could make overtime work or participation in training courses relatively more costly for women, so that they would find themselves in a "mommy track", with lower advancement prospects. Finally, Booth, Francesconi and Frank (2003) showed that in the case that female workers suffered discrimination in the form of worse job market opportunities than males, they would have equal or higher promotion chances than men, but they would obtain lower wage increases upon promotion and they would quit less for better jobs ${ }^{6}$. All these theories assume that organisations' promotion rules are equal for women and men. Therefore job-related characteristics that may affect promotion prospects (e.g.- overtime work, participation in training...) should have similar effects for men and women. Moreover, any potential difference in promotion rates should disappear as long after one can effectively control for effort exerted or training carried out. Wage increases observed upon promotion, however, may be higher for women because of selection issues (Lazear and Rosen, 1990) or lower because of discrimination (Booth et al., 2003).

As it can be observed in the first column of Appendix A, most theories agree in that workers' cumulated human capital plays an important role in filling in higher-level jobs of an organisation, so that the empirical analysis of the effect of training on promotion prospects is far from a complete discriminatory check. Instead, it is presented in the next section as a first approach to the issue, complemented later with more specific pieces of evidence aimed to disentangle which of the existing theories is the most likely "driving force" of the registered stylised facts.

\footnotetext{
${ }^{6}$ Alternatively, the authors propose that, if discrimination comes in the form of lower propensity of challenged employers to match outside offers, female workers would quit more for better jobs.
} 


\section{Evidence about Training, Careers and Wages}

The most direct way to check how employees' human capital affects their task allocation is perhaps to investigate whether the job-related training received by a worker affects his future career path, either within or outside the training firm. This is what it is done along this section, first by estimating how (internal and external) promotion probability is affected by training and other job-related variables and then by analysing to what extent the returns to training received by a worker are dependent on whether he/she steps forward in his career or not.

\section{Data and Econometric Method}

To address the first issue, I use the job history data recorded in the BHPS jointly with the job-related individual questions of the survey. Each year, individuals are asked about any change in their job status and, in case of having stopped doing the job reported in the last year, they are asked about the reasons of $i^{\mathrm{t}}$. I used the answers to these questions to create a dichotomous variable registering the event of a "promotion with current employer" between $t$ and $t+1$ whenever a worker stated, in the interview at $t+1$, that $(i)$ he/she had stopped doing the job that he/she was doing at the moment of the interview at $\mathrm{t}$, that (ii) he/she had started doing a different job for the same employer, and that (iii) such job change was a promotion ${ }^{8}$. An analogous variable was created to code whether the worker quitted his/her current employer between $t$ and $t+l$ for a better job elsewhere. There is a potential problem of endogeneity in that promotion may itself involve the provision of further training. To avoid it, promotion between $t$ and $t+1$ is analysed in relation to a set of individual and job characteristics observed at t. The main variable of interest is then training received by the worker between $t-1$ and $t$, measured both in terms of events and

\footnotetext{
${ }^{7}$ See Appendix B for the exact code of questions.

${ }^{8}$ Therefore, the concept of promotion considered here is defined by the subjective perception of the employee obtaining it.
} 
intensity, in order to permit higher flexibility ${ }^{9}$ in the estimation. The drawback of this method is that, as long as some of the training might have an immediate effect on the probabilities of obtaining a promotion, this effect may not be reflected in next year's promotion outcomes and the estimates may suffer a bias towards zero.

Since the analysis of this paper focuses on both dychotomic outcomes (career moves) and continuous dependent variables (wages), both qualitative and standard regression analyses are carried out. The panel nature of the BHPS allows the researcher to account for unobserved effects when estimating the probability of promotion and the determinants of wages. Specifically, the efficiency of the estimation can be improved through the integration of individual-specific effects as random. However, if such individual effects were correlated with the explanatory variables, a fixed-effect approach would be needed to obtain consistent estimates. It is likely that unobserved variables, such as motivation of the worker, natural ability or quality of the match with the employer affect both the promotion chances of an individual and the incidence of training. Therefore, I estimated the probability of a career move through a logit model, which is the only non-linear model that allows one to obtain consistent estimates through a fixed effects-like approach. In the case of wage regressions, the standard differences in differences (fixed-effect) approach was considered. To account for employer match-specific effects that could affect withinindividual variations, I introduced a set of dummy variables accounting for each employer change in the case of fixed effects estimators.

The Logit specifications considered here estimate the probability of each type of career move as a function of a set of individual and firm characteristics, a set of year effects, an individual effect and a random disturbance. Considering the individual effect as fixed implies a loss in the efficiency of the estimation with respect to the random effects

\footnotetext{
${ }^{9}$ Since the measure of job related training available in the BHPS only specifies who bears (in theory) the costs of job-related training for the sub-sample of the last five years, I will interpret the results assuming that both employers and employees are involved in one way or another in the effort to increase the value of human capital.
} 
specification as long as the obtained estimates in the latter case are consistent. Nevertheless, if unobserved worker characteristics were causing a bias in the estimation of the parameters of the model under a random effects specification, the fixed-effect method is more appropriate, since it allows the researcher to estimate the effects on probability of time-variant variables while keeping constant both observed and unobserved individual characteristics. The logit fixed-effect that would be suitable in this case is analogous to that developed in Chamberlain (1980), based on a differences in differences approach, where time-invariant explanatory variables are eliminated from the estimation. In the next subsection, I explore both methods to estimate the probability of internal promotion including as an additional regressor, in the case of the random-effects specification, a variable indicating whether the worker received a promotion in the last year. This is done in order to attenuate the potential bias caused by unobserved characteristics $\frac{10}{10}$ under such specification. The analysis of the probability of quitting for a better job is done analogously, and also includes the mentioned explanatory variable, since past promotions (or the lack of promotions) may crucially affect workers' quitting decision.

Our sample of British workers includes 37140 observations from 7894 workers, between 16 and 64 years old, working neither at the public sector nor at the armed forces, who had valid recorded data for all of the variables of interest. Some descriptive statistics of these variables can be found in Appendix C. It is remarkable that women are reported to earn around $27 \%$ lower wages than men (similar to the raw wage gap typically calculated for the $\mathrm{UK}^{11}$ ) and that they obtain significantly less promotions, on average, than men $(6.4 \%$ of female workers achieve an internal promotion each year while up to $8 \%$ of males obtain it). Such glass ceiling observed for internal promotions 12 is not found in quits for better jobs, where sex differences were not significant $(8.6 \%$ of female workers and $8.9 \%$ of males quit their firms for a better job each year). This already suggests that women's careers are

\footnotetext{
${ }^{10}$ Note that such variable is not exactly a lagged dependent variable, since it also includes promotions obtained with employers other than the current one.

${ }^{11}$ See, for example, Perfect and Hurrell (2003).

12 Note that Booth, Francesconi and Frank (2001) did not find such glass ceiling in their analysis. Such mismatch is likely to be due to the fact that they focused only on full-time workers, while the present work also includes employees working less than 30 hours a week.
} 
relatively more attached to the external job market than that of men, as it is confirmed by the different pieces of evidence presented along this paper.

\section{Results: Probability of a Career Move}

Table 1 shows the Odds-Ratio estimates obtained from the logistic regressions of the probability of obtaining career improvement with either current employer (i.e. promotion), or a different one (i.e. quit for better job). The figures represent how an additional increase

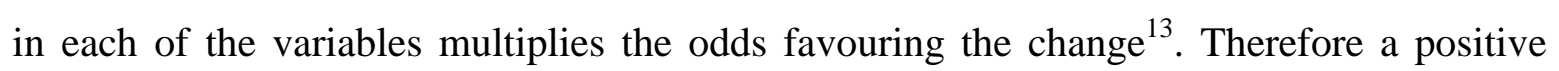
(negative) effect in probabilities is associated to Odds-Ratios higher (lower) than one. For each gender, I estimated the probability of obtaining a promotion and the probability of quitting for a better job through both random effects and fixed effects specifications. The strong differences across models observed in some of the estimates suggest that personspecific and match-specific effects are relevant issues to control for in this type of analysis. Although a Hausman test could not be performed with these data, I also estimated an intermediate random-effects model that allows for correlation between individual effects and the individual means of the rest of explanatory variables, analogous the one proposed in Chamberlain (1980). The results were much more similar to those yielded by the fixedeffects approach than to those of the standard random-effects, supporting somehow the need of controlling for unobserved individual heterogeneity, and suggesting that results obtained through the fixed-effect approach are more reliable.

As it can be seen in Table 1, last year training incidence has a significant positive effect on promotion chances for both men and women in the random-effects specification. When considering the individual effects as fixed, however, the odds-ratio drops dramatically towards one for men (losing its significance), while it is also slightly reduced for women.

\footnotetext{
13 Odds-Ratios have been presented instead of marginal effects at the mean because the latter are sensitive to the distribution of individual effects. Since Conditional (fixed-effects) Logit does not allow one to compute the individual effects, it is not possible to know their true distribution, nor to obtain the corresponding marginal effects. On the other hand, Odds-Ratio estimates from the logit model are constant across all the values of other variables.
} 
Similar patterns can be observed in Table 2, where different versions of the same regression including different measures of training incidence and intensity in the last two years are shown. In all cases the effect decreases and becomes non-significant for men, while it remains relatively large and significant for the sample of women $\frac{14}{14}$ The effects seem to be larger if one considers all the training received in the last two years, suggesting that its impact on internal career prospects may be persistent over time. As for the effect of the training received on the probability of quitting for a better job, no clear conclusion can be drawn from the results displayed in Table 2: Training seems to slightly decrease the probabilities of switching employers for the sample of male workers while increasing the chances for the sample of women. These results, although consistent across specifications, are mostly not significant. Back to Table 1, it can be observed that the effect of other variables usually associated to human capital, such as job market experience or job tenure, are also strongly affected by the presence of unobserved heterogeneity. Chances of promotion decrease with job tenure for both male and female workers in the random-effects specification. Controlling for unobservable effects, however, the relationship takes inverted $\mathrm{U}$ shape for both genders, with probabilities of promotion increasing during approximately the first two years and decreasing afterwards. Previous job market experience, on the other hand, does not seem to have any significant effect. The odds that a worker switches employers to a better position strongly decrease with tenure and, to a lower extent, with his/her job experience with previous employers.

Table 1 also shows the effect of other job-related characteristics on the probability of promotion. While a temporary worker is clearly less likely to obtain a promotion than a permanent one (the omitted category), the effect is not that clear for fixed-term contract holders: the strong negative effect observed in the random-effects estimation for both genders becomes non-significant when we control for unobserved effects, suggesting that workers with poor promotion prospects are usually selected into fixed-term contracts. It is

\footnotetext{
14 These results follow a similar pattern to those of Pergamit and Veum: in their Probit analysis of the probability of Promotion between 1989 and 1990 as a function of the training received between 1988 and 1999, they found that the effect were larger for women than for men and that the effect registered for the sample of men were not significant in conventional terms.
} 
also remarkable that women with fixed-term contracts tend to quit for better jobs significantly more than permanent ones, while male workers do not. Overtime work and part-timer status have both strong impact, positive and negative respectively, on promotion chances. It is noticeable, however, that the estimated effects decrease to non-significant values for the sample of female workers when we control for unobserved individual and match effects. Working at an unionised firm seems to yield higher chances of internal progress to male workers, especially if they do not belong to the union; this result follows a similar pattern for women, although in their case estimates are smaller and not statistically significant. The results also show that workers of both genders are less willing to quit for a better job when they are employed at unionised firms. Both types of findings fit well into the classical view of unions as protecting organisation's current employees against the competence of prospective ones, in this case by favouring the filling of vacancies through promotions instead of through external hires.

Recently promoted workers seem more likely to obtain a future promotion and tend to quit less than the rest. More educated workers, for whom previous studies have obtained ambiguous conclusions about their promotion probabilities (see McCue, 1996), appear to have higher chances of internal progress than less educated ones, suggesting that they follow "steeper" careers than the less educated counterparts. It is far less clear whether they are also more willing to switch firms in the search of better jobs.

The positive effect of training on the probability of internal promotion registered for the sample of British women is consistent with most theoretical models. In the case of male workers, the effect is surprisingly small and not significant for the within-group estimates. Furthermore, there is a stronger effect of full-time and overtime work on promotion chances for the group of men. Jointly, these findings reveal a substantial difference in the relevant driving forces of promotion for male and female workers. In particular, promotions appear more related to measures of effort and commitment with the firm in the case male workers (in terms of working hours) and to human capital accumulation (in terms of jobrelated training) in the case of females. Such human capital accumulated through training, however, does not seem to be firm-specific, since it is not related to lower probabilities of 
quitting for better jobs. Rather, the concave relationship between job tenure and promotion observed here as well as in most of previous empirical literature $\sqrt{15}$ is more consistent with models that consider (symmetric or asymmetric) employers learning than those about incentives 16 .

\section{Results: Wage Returns to Training and Promotion}

Another way to check that helps to figure out how accurately different theoretical models fit task-assignment practices at British firms is the joint analysis of wage returns to training and promotion. Given that the displayed evidence shows a correlation (especially significant for women) between job-related training receipt and future promotions, the evaluation of the returns that workers receive from the training investment must control for position upgrade. Otherwise such returns could be largely reflecting a better assignment of workers' skills. For analogous reasons, the estimation of wage increases upon promotion must account for training receipt. Finally, it seems plausible that both training and promotions have interdependent effects on wages, as the different theoretical approaches seem to predict. Therefore, an interaction of the impact of both actions is suitable in the wage regression analysis.

To account for these issues, the empirical model of wage-determination considered here will take the following shape:

\footnotetext{
${ }^{15}$ Francesconi (2001) divided workers in four tenure groups and found that belonging to the third one had the highest effect on probability of promotion. Pergamit and Veum(1999) estimated a negative quadratic effect, while McCue(1996) only found a positive linear effect on the hazard rate of promotion.

${ }^{16}$ In the case of symmetric learning, acquisition of information about workers' skills reaches at some point decreasing returns, and tenured workers' promotions are less frequently due to updates in information about their ability. If employers learn asymmetrically such information, the cost of promoting a worker in terms of disclosing such information to the market is higher in the case of tenured workers. From the point of view of incentives, however, there is not a clear reason to think that tenured workers should be offered less possibilities of promotion than more junior employees.
} 
$\ln w_{i j t}=X_{i j t}{ }^{\prime} \beta+P_{i j t} \theta+T_{i t}{ }^{\prime} \alpha+P_{i j t} T_{i t}{ }^{\prime} \gamma+Y_{t}{ }^{\prime} \delta+\mu_{i}+v_{i j}+\varepsilon_{i j t}$

Where $\ln w_{i j t}$ is the logarithm of the real hourly wage of individual $i$ with employer $j$ at time $t$; the vector $X_{i j t}$ includes a set of individual and firm characteristics that may affect wages; $P_{i j t}$ is a dummy variable taking the value one if the worker has been promoted by his/her current employer and zero otherwise; $Y_{t}$ is a vector of year-specific dummies and $T_{i t}$ represents different measures of job related training. I considered separately the training that individuals received while working for previous and current employers. In a similar fashion to Booth and Bryan (2002), I considered all the training accumulated by the worker

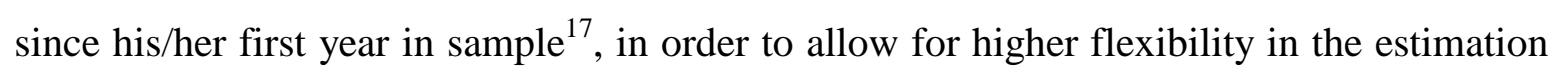
of the returns to training and attenuate any possible bias induced by measurement error. The variance in wages not explained by observable characteristics is segregated into an individual fixed component $\mu_{i}$, a worker-employer match effect $v_{i j}$, and a transitory shock $\varepsilon_{i j t .}$ Potential correlation of the observed explanatory variables with the unobserved effects $\mu_{i}$ and $v_{i j}$ would lead, in principle, to biased estimates of the coefficients. I addressed these problems by estimating the model through a fixed-effect approach (identifying the slopes through within-individual variation) and including as explanatory variables the same set of dummies used previously in the Logit analysis to track the different employer matches of each worker.

Table 3 reports the most relevant estimates of different versions of equation (1) when training is measured through the cumulated number of training events carried out along the sample period $\frac{18}{1}$. Models I and II refer to estimated returns to training and promotion respectively. The estimated wage returns to job-related training are relatively close to those obtained by Booth and Bryan (2002) for the 1998-2000 waves of the same data. Male and female workers are expected to obtain respectively $1.6 \%$ and $1.9 \%$ permanent wage increases wage increases from each training event with their current employers. Controlling

\footnotetext{
${ }^{17}$ See Booth and Bryan (2002) for a further discussion of the advantages of this approach.

${ }^{18}$ Given that during the first 7 waves of the sample it is only recorded whether the employee received training or not, I will count at most one event each year.
} 
for promotion (Model III), these figures are slightly reduced (to $1.4 \%$ and $1.8 \%$ respectively). The interaction of training and promotion (Model IV) is positive and significant only in the case of men, being their expected returns to training some $1 \%$ higher after obtaining a promotion. Training events with previous employers produce more uneven results: while women are expected to obtain $2.2 \%$ wage increase from them, the estimated effect for men is around $0.4 \%$ and not statistically significant. These effects are quite similar, $2.1 \%$ and $0.6 \%$ respectively, when we control for promotion receipt. The interaction between training received with previous employers and promotion is strongly negative although not statistically significant for both genders. In summary, a large part of the observed returns to training is independent of promotion attainment, although the only significant interaction found between both actions is highly positive. Model II reports $7 \%$ and $7.5 \%$ wage increases upon promotion for male and female workers respectively 19 . These figures are reduced to $6.7 \%$ and $6.9 \%$ when we control for training receipt. The significantly positive interaction between training and promotion mentioned above for male workers makes men's returns to promotion somewhat dependent on training received with current employer. Such returns are expected to increase by $1 \%$ with each additional training event carried out in the past, starting from a 5.4\% wage increase for a non-trained worker. Voluntary quits to better jobs seem to reward workers worse than promotions in the short run: extra wage increase expected upon quit is only around $2 \%$, with similar figures for men and women 20 .

All the theoretical approaches described in the previous section fit well the fact that wage increases are higher when promotion occurs. A more interesting result is the observed significant returns to training accrued by workers when controlling for promotion and the

\footnotetext{
${ }^{19}$ These returns are slightly more even to those obtained by Francesconi (2001) for the first five waves, who registered $7 \%$ and $4 \%$ wage increases for men and women respectively. Similar figures around $8 \%$ were found by Brown (1989) and Pergamin and Veum (1999) for the American's representative PSID survey and young workers' NLSY respectively.

20 These results are also close to those obtained by Pergamin and Veum (1999), who found that switching employers yielded American young workers 3\% wage increases. Long-term cumulative wage growth, however, has been estimated to be much more affected by separations than by within-job mobility, especially for young workers (see Topel and Ward (1992) and McCue(1996))
} 
relatively high value of training even when promotion is not achieved. The fact that workers do not have to wait until promotion to pick up returns to training suggests that promotion prospects are not the main motivation to make an effort in obtaining human capital. On the other hand, the estimated interactions between training and promotion in wage growth yield inconclusive results: the only significant estimate depicts a positive effect for men, which supports both the incentive-oriented and gradual-learning stories for this group, while other estimates are negative, more in the line of the private-information setting.

Summing up, the evidence from both types of analysis seems to encourage more a view of promotions as a consequence of human capital accumulation (and maybe employers learning) than as a device to encourage the acquisition of specific skills. This is specially true for the sample of women: their training has a positive impact on probabilities of promotion and on probabilities of quitting for a better job and their returns to training are quite independent of promotion achievement The case of male workers is more ambiguous; their promotion prospects are not significantly boosted by their participation in training and their wage returns to training do not change very much when we control for promotion achievement. However, some of the evidence presented in this section for male workers is consistent with an institutional view of promotions as mechanisms to induce effort at job: working longer hours has significant effect on their promotion prospects, and the wage returns from the training carried out with their current employers are significantly larger when a promotion is also achieved.

With respect to gender differences in promotions, pooling the samples of men and women revealed that, other things being equal, women are slightly more likely to receive promotions and significantly less likely to quit for better jobs. This is consistent with either women having higher costs of mobility or suffering discrimination by potential "poacher" employers, although this latter explanation would be challenged by the slightly higher wage increase upon job quit that the presented evidence allocate to female workers. The most striking implication from the results of this section, however, is that is that the gender gap in earnings is difficult to explain in terms of a single theory of career paths as it has been 
traditionally done in the literature. In contrast, the driving forces of career progress seem to be different for male and female workers. The career progress of men appears more related to internal labour markets structures, with an important role of effort and training carried out within the firm. Conversely, women's careers are more closely related to the value of their human capital, as shown by the fact that their training with previous employers affects positively their employment with prospective ones, in terms of both salaries and quality of job held.

Despite the trends pointed by the findings of this section, most of the results depicted are consistent with several theories. In the next Section, I deal with this issue by presenting additional evidence that can be used as more specific checks for the described models.

\section{$\underline{\text { Additional Evidence }}$}

In order to obtain more discriminatory evidence of which of the explained forces has a stronger role behind the stylised facts about task assignment and career paths, I move now into more concrete aspects of the analysis of career progress where different theories either disagree in their predictions or at least differ in their capacity to fit the evidence.

\section{Within-position wage growth after promotion}

Predictions on how should wages evolve after promotion differs across different theories. Symmetric learning predicts a positive effect: if promotion is correlated with positive updates in the market belief about employee's ability, then he/she is also expected to accumulate human capital faster after promotion and therefore, obtain higher wage increases. Theories of asymmetric information will also foresee higher wage increases after promotion as long as promotion discloses to the market that the employee is able to accumulate human capital faster than initially expected. Finally, theories that consider promotion systems as the incentive to effort either in job tasks or in learning specific skills will predict low levels of within-job wage growth at any position within the firm. To analyse the effect of promotions on subsequent wage increase, I ran a number of 
regressions having as independent variable the yearly increase in log wages within position $\left(\ln w_{i j t+1}-\ln w_{i j t}\right)$, including therefore only observations with two subsequent years observed at $t$ and $t+1$, when no job change was observed ${ }^{21}$. The regression estimates, not presented here, did show significant influence of promotion receipt on within-position wage growth. Most estimated effects were of low absolute values and both positive and negative estimates were found for different specifications. Only quits for better job seemed to have a positive significant effect on subsequent wage growth for the sample of male workers

\section{General and Specific Human Capital}

The information recorded in the BHPS concerning job related training of individuals also included several questions about the aim of the training received (if any). The last of these questions - "Was any of this training to develop your skills generally?”- will be exploited to explore the relationship between training and promotion in terms of Becker's extended split of human capital into general-purpose and firm-specific types $\underline{23}$. If promotions were granted to workers as prizes for their effort in learning firm-specific skills, the provision of specific training should have larger effect on promotion chances than general training. In addition, the returns to specific training accrued by workers' wages should decrease considerably when controlling for promotion achievement and the interaction between specific training and promotion should have positive and relatively large effect on wages. Conversely, if task assignment were determined by employers' progressive learning of

${ }^{21}$ This regression has been estimated through a fixed-effect approach, yielding a "differences in differences of differences" method to account for unobserved heterogeneity that could be correlated with both wage growth and probability of promotion.

${ }^{22}$ Specifically, quits for better job are expected to increase future within-position wage growth by additional $2.2 \%$ for men and between $1 \%$ and $2 \%$ for women. The estimated effects of promotion range between $-0.2 \%$ and $0.5 \%$.

${ }^{23}$ Here I interpret as firm-specific all the training that the worker declared it was not aimed to develop his/her skills generally. It may not be true that the features of the training that lead a worker to consider it as "not general" must be purely firm-specific; rather, they will be task-specific in most of the cases. Nevertheless, even the definition of firm-specific human capital is usually associated to combination of task-specific skills and therefore the chosen measure of "non general" training should be a good measure of firm-specific human capital. 
workers' ability, promotion receipt would be similarly affected by general and specific training as long as both are equally useful at higher-level tasks. Theories remarking the role of current employer's private information yield more uneven predictions: the cost of promoting an employee (in terms of wage increase associated to information disclosure) that faces an incumbent employer is higher when the skills of the worker are more general (Bernhardt, 1995). This is because any increase in his/her expected productivity with other potential employers will depend on the versatility of his/her skills 24 . Therefore general training should be less strongly correlated (or even negatively correlated) with chances of future promotion than specific training. Moreover, the effect of the interaction between promotion and general training in the wage equation must be higher than that of promotion with specific training.

The odds ratio estimates showed in Table 5 for the probability of promotion reveal that unobserved heterogeneity affects more the estimated effect of general training than the effect of specific training. The significant and important impacts of general training obtained in the random-effects specification for both genders disappear when we individual and firm effects are accounted for. The effect of specific training is only statistically significant for the sample of women, but it remains large even after we control for unobserved heterogeneity, consistently both with the asymmetric information story and the incentives-based explanation. Female workers are more likely to leave their firms for better jobs after receiving general job-related training and, as Table 6 shows, they are able to obtain higher returns to the general training carried out at previous employers than their male counterparts. Indeed, while male workers only obtain significant returns to the training (general or specific) done with their current employers, women get significant returns to general training around $2 \%$ per event, independently of the firms employing them during the training. These findings suggest again that there are substantial differences in the structure of career patterns for male and female workers, with women's possibilities of progress more attached to the market value of their skills.

\footnotetext{
${ }^{24}$ Note that this argument assumes the existence of complementarities between ability and learned skills: more able workers are capable to make a better use of general (and specific) skills.
} 
A comparison of the figures corresponding to the effect of specific human capital across the three different models proposed in Table 6 discourages an "incentives to invest"-based view of promotions: returns to specific training with current employer do not vary when we control for promotion receipt (about $2.1 \%$ for male workers and non-significant $0.9 \%$ for females), and the estimated interactions between current employer specific training and promotion in the wage equation, although positive for the sample of men, are not statistically significant in any case. The predictions from private information stories are neither corroborated by this data. They forecast higher wage increases upon promotion when the upgrading is awarded jointly with general instead of specific training. This result is only found for the sample of women, as it can be observed from a comparison of the interactions presented in the last two columns of Table 6. Even in that case, the differences are small and not statistically significant.

\section{Differences by Age Groups}

It is well known that labour market mobility, both within and across firms, is higher for young workers than for older ones. Here, I will go a step further and analyse, for different age groups, how training affects promotion probabilities, and how both actions affect wage growth. Theoretical models that consider (symmetric) learning as a key factor in promotion dynamics predict larger updates in the beliefs of ability for younger workers, so that their training should be more strongly correlated with future promotion and their training and promotion should provide them with larger wage increases. If promotion dynamics were conditioned by the private information hold by current employers about their workers' ability, younger workers would suffer more from the problem of asymmetric information. Therefore, they would obtain higher wage increases upon promotion and their training would be especially correlated with promotion receipt. Finally, the incentive role of promotions remarked by other theories does not forecast different relationship between training and promotion for different age groups. These theories suggest, however, that the wage increases upon promotion needed to provide older workers with the right incentives to put effort should be higher that those offered to younger ones. This is because employers 
have to compensate the lower "option value" that a promotion contains for workers coming close to the end of their career (Rosen, 1986).

Table 7 shows the estimated odds-ratio effects of previous year training incidence on promotion chances for four different age groups: "twenties", "thirties", "forties" and "older" 25 . The results are less than conclusive for the sample of men. The effect is relatively high for young men in their twenties and thirties in the random effects specification, but the strongest effect (and the only positive and significant one in the within-group specification) corresponds to the group of older workers. Results for female workers fit relatively well to the predictions of both information-oriented type of models. The correlation between training and future promotion chances is clearly higher for younger groups of females than for older ones in both random-effects and fixed-effects specifications. The effect of training receipt on the probabilities of quitting for a better job is not significant for most age groups, but it must be noticed that such effects evolve with age in opposite ways for males and females. Younger women are more likely to quit for a better job if they have received training while older women are less likely to do it; the reverse seems to hold for male workers 26 .

Table 8 shows the effects of training, promotion and quits on wages for the four different age groups, following the preferred specification of equation (1) in terms of parsimony, which excludes interactions.

Results strongly favour the implications of information-related theories of task assignment dynamics and discourage a global interpretation of promotions in terms of incentives to invest in human capital. With the exception of "older" women, who obtain larger wage increases on promotion that women in their thirties and forties, estimated wage increases

25 The "twenties" group includes all workers who were under 31 years old by 2002, "thirties", includes all workers between 31 and 40, "forties" includes those workers between 41 and 50 and "older" those over 50.

26 The stronger correlation between training and quits found for young females with respect to older ones fits well the possibility that their training discloses information about their ability or turns them "more visible" (in terms of Milgrom and Oster, 1987). The converse effect found for male workers is more striking and does not seem to fit well with any of the existing theories. 
upon promotion are systematically lower for older groups of both genders -from expected wage increases of $9.17 \%$ for men below 30 to $2.78 \%$ for oldest males. Returns to training are also higher for younger workers. This fact is especially consistent with theories of learning or information disclosure, but it may be also reflecting the higher facility for learning that younger individuals have. Younger workers also seem to get higher wage increases from quits to better jobs, although this finding is harder to interpret, since the concept of "better job" is likely to be different for different age groups.

In sum, segregating our results by age groups yields a similar flavour to the joint analysis of previous section. Female careers seem to fit well in a model of dynamic learning, with more uncertainty about the ability of younger workers, whose promotion is more related to training receipt and who tend to enjoy higher wage increases upon promotion. The evidence for the sample of males, with younger groups whose training does not affect especially their promotion chances, is far less certain.

\section{Differences by Seniority Groups}

Some important variables whose effect on task allocation of workers has been discussed along this paper may differ across tenure levels. More senior workers are also more experienced ones, but they are surely also employees with more specific human capital.

In a framework of symmetric information learning, differences in workers' tenure are not relevant for the dynamics of their allocation to tasks, and any difference we may find by seniority groups should be only reflecting the different age and experience levels. Things are more complex, however, in a setting of private learning. In that case, higher tenure may imply a higher informational advantage for current employers, making worse the problem of asymmetric information and increasing the correlation between training, promotion, and wage growth. On the other hand, as long as more tenured workers are also older and more experienced, there will be less uncertainty about their ability in the labour market and such correlation could be lower for them. Thus, private information theories yield ambiguous predictions about more tenured workers, since their ability is less uncertain to the labour 
market, but different employers know it more asymmetrically. The provision of incentives through promotions it is also likely to be affected by tenure in two ways. First, the evaluation of tenured workers can be more accurately based on long term, more subjective, measures of performance and commitment, losing their relative weight more naive measures such as participation in training programs. Second, more tenured workers are also more likely to be closer to the end of their careers or to their top at the employer organisation; therefore their category upgrade must involve higher wage increases if it is designed to motivate them. In brief, an "incentive-provider" promotion should be less dependent of training receipt and imply an especially high wage increase to compensate its lack of option value

Table 9 displays the estimated effects of several important variables on the probability of obtaining a promotion. The estimated model is the same Logit model used in previous section with a random-effects specification $\underline{27}$ with different effects for different levels of seniority. Since there is not any specially useful rule to delimit the seniority groups, I decided to create 4 groups with an homogenous number of observation, using therefore the three quartiles of the sample distribution of seniority as cut-off points (set at 28, 73 and 159 months). This piece of evidence does not show any important differences by seniority levels in the effects of training on promotion probabilities for neither gender. For the sample of men, it seems that the training of more tenured employees is more strongly related to promotion than the training of rookies, but the estimated differences are not statistically significant. The ambiguous effect predicted by asymmetric information theories accommodates better this result than any of the other models described here.

One important aspect in the interpretation of the observed effect of job-related variables on promotion achievement is that different models may be more valid than others at different

\footnotetext{
27 A fixed effects specification is not suitable for the analysis with segregated simples; since different observations from the same individual switch frequently from one category to another, the cell size remaining to estimate a Conditional Logit would be too small to obtain accurate estimates. On the other hand, results from the random effects specification must be interpreted carefully, since unobserved heterogeneity across individuals might be biasing them.
} 
points in the career of a worker. Matching tasks to the observed skills could be, for example, a priority with respect to junior employees. On the other hand, motivating them increases its importance as they become more tenured and the threat of dismissal is too costly to be credible. This would be consistent with the observation that, for tenure levels around the median, overtime work has larger effect on promotion prospects and the achievement of a promotion in the last year has slightly lower effect. These differences in the impacts, however, are mostly not statistically significant and their sign is reversed for most tenured group.

Table 10 shows the effect of training and promotion on wages for the four seniority groups. The first row reveals that male employees obtain higher returns to training with current employer than their more tenured counterparts (as information-related stories predict), while there is no clear trend for the sample of women. Training hold with previous

employers appears less and less valuable for more senior workers of both genders, with a striking highly negative effect over the wages of most tenured workers. The most interesting finding here is that senior male employees obtain generally higher wage increase upon promotion compared to less tenured males (as predicted by the theory of incentives), while exactly the opposite holds for female employees (as predicted by symmetricallylearning models). This suggests again that the career of men are more affected by incentives issues within their firm, while the occupation of women seem to be more related to their fit to each of the task and the information available about in the market about their skills.

\section{Conclusions}

Although the evidence presented in along this paper reveal that none of the existing theories regarding human capital and tasks assignment is definitively superior to the rest of them in explaining all the findings, some theories are more handicapped than others by the analysis reported here. The facts that non-promoted workers receive high returns to specific training and that younger employees receive higher returns upon promotions are difficult to reconcile with a view of promotions as incentives to invest in firm-specific human capital, 
since its predictions go in exactly the opposite way. The facts that trained workers do not obtain lower wage increases on promotion than untrained ones and that generally trained workers do not receive significantly higher wage increases on promotion than specifically trained ones undermine the private information story. The first issue can be justified by neglecting the signalling power of training provision; the second one is more difficult to overcome, since the value of the natural ability of a worker is likely to be also largely dependent on the skills he/she has acquired.

Globally, the theory that fits best the results presented in this paper is the symmetric learning approach, represented by the comprehensive model of Gibbons and Waldman $(1999,2003)$. Its main drawback is the unfulfilled prediction of larger within-position wage growth after promotion. However, several arguments can be supplied to justify this fact without moving out of the theoretical framework. Employees' rates of human capital accumulation, for example, may vary across positions, being lower at higher ranks of a hierarchy where the cost of learning by doing is higher in terms of wrong decisions and forgone time used. Similarly, employer's learning rate about workers' ability may also be lower for top managers skills are better known.

A relevant result from is the strong gender differences found in the relationship of training and career prospects. Females' career progress is more related to their training activities, especially for younger and less tenured women, who also obtain higher wage increases upon promotion or quit for better job. In particular, receiving specific training has a larger influence on women's internal promotion chances, while general training has a larger effect on outside progress. All this seems to place women's career structures in the line of symmetric learning human capital accumulation and spot market contracting settings. Men's chances of career progress seem less affected by training receipt and such weak relationship is less dependent on the age of the worker. Moreover, "full time worker status" and "doing overtime work", two variables that are likely proxies of employees' effort and commitment to the organisation, seem to have higher effects on promotion prospects. Additional evidence shows that men obtain higher wage returns to specific training and slightly lower wage increases on quit for better jobs than women, and that more senior 
workers (whose promotion is likely to include a lower "option value") obtain higher wage increases upon promotion. This yields a mixed picture of men's careers, which includes more elements of internal labour markets and the institutional role of promotions (as incentive provider) than in the case of women. Such institutional role, however, would seem designed to encourage the effort of workers by rewarding overtime work, rather than to promote the acquisition of specific human capital.

The consequence for the existing theories that link the gender gap in earnings to career development dynamics is that narrow models with tightly defined determinants of promotion are not accurate. Rather, future research about the processes in the career building of workers that lead women to their well-known earnings disadvantage must take into account that even small differences in females" "initial conditions" at their entry in the labour market (for example, their lower expected probability of staying in the labour force, lower expected working hours in the future, or any systematic discrimination practice carried out by employers) may prevent their participation in certain long-term relational contracts and induce their selection into more spot market-oriented frameworks of labour relationship. 


\section{$\underline{\text { References }}$}

Baker, G.P., M.C. Jensen and K.J. Murphy (1998): "Compensation and Incentives: Practice vs. Theory," Journal of Finance, No. 43, 593-616.

Baker, G.P., M. Gibbs and B. Holmstroom (1994): "The Internal Economics of a Firm: Evidence from Personnel Data," Quarterly Journal of Economics, vol 109, 881-919.

Bernhardt (1995):"Strategic Promotion and Compensation," Review of Economic Studies, vol 62, 315-39.

Booth, A.L. and M.L. Bryan (2002): "Who Pays for General Training? Testing some Predictions of Human Capital Theory," IZA Discussion Paper 486.

Booth, A.L., M. Francesconi and L. Franks (2003): "A Sticky Floors Model of Promotion, Pay and Gender," European Economic Review, vol 47, 295-322.

Brown, J. (1989): "Why Do Wages Increase with Tenure? On-the-Job Training and LifeCycle 'wage Growth Observed within Firms," American Economic Review, vol 79, No. 4, 971-991.

Carmichael, H,L. (1983): "Firm-Specific Human Capital and Promotion Ladders," Bell Journal of Economics, vol 14, 251-258.

Chamberlain, G. (1980): "Analysis of Covariance with Qualitative Data," Review of Economic Studies, No. 47, 225-238.

Chang, W. (1996): "External Recruitment versus Internal Promotion," Journal of Labor Economics, vol 14, No. 4, 555-570. 
Doeringer, P.B. and M.J. Piore, (1971): Internal Labour Markets and Manpower Analysis. Heath, Lexington: Lexington Books.

Fairburn, J.A. and J.M. Malcomsom (2001): "Performance, Promotion and the Peter Principle," Review of Economic Studies, vol 68, 45-66.

Francesconi, M. (2001): "Determinants and Consequences of Promotions in Britain," Oxford Bulletin of Economics and Statistics, vol 63, 279-310.

Gibbons, R. and M. Waldman (1999a): "Careers in Organizations: Theory and Evidence," in Ashenfelter, O. and D. Card (eds.): Handbook of Labor Economics, vol 3B. Amsterdam: North Holland.

Gibbons, R. and M. Waldman (1999b): “A Theory of Wage and Promotion Dynamics inside Firms," Quarterly Journal of Economics, vol. 114, 1321-1358.

Lazear, E.P. and S. Rosen (1981): "Rank-Ordered Tournaments as Optimum Labor Contracts," Journal of Political Economy, vol 89, 841-64.

Lazear, E.P. and S. Rosen (1990): "Male-Female Wage Differentials in Job Ladders," Journal of Labor Economics, vol 8(1), S106- S123.

McCue, K. (1996): "Promotions and Wage Growth," Journal of Labor Economics, vol 14, 175-209.

Medoff, J. and K. Abraham (1981): "Experience, Performance and Earnings," Quarterly Journal of Economics, vol 95, 705-736.

Milgrom, P. and S. Oster (1987): "Job Discrimination, Market Forces, and the Invisibility Hypothesis," Quarterly Journal of Economics, vol 102, 453-476. 
Perfect, D. and K. Hurrell (2003): Pay and Income: Women and Men in Britain Series, Equal Opportunities Commission, UK.

Pergamit, M.R. and J.R. Veum, (1999): "What is a Promotion?," Industrial and Labor Relations Review, vol 52, 581-601.

Prendergast, C. (1993): "The Role of Promotion in Inducing Specific Human Capital Acquisition”, Quarterly Journal of Economics, vol 102, 523-576.

Rosen, S. (1986): "Prizes and Incentives in Elimination Tournaments," American Economic Review, vol 76(4), 701-715.

Sicherman, N. and O. Galor (1990): “A Theory of Career Mobility”, Journal of Political Economy, Vol. 98, No. 1, pp. 169-192.

Topel, R. H. and M. P. Ward. (1992): "Job Mobility and Career of Young Men," The Quarterly Journal of Economics, vol 107(2), 439-479.

Waldman, M. (1984): "Job Assignments, Signalling and Efficiency", Rand Journal of Economics, vol 15, 225-267. 


\section{$\underline{\text { Tables }}$}

Table 1: Effect of Last year Training Incidence on Probabilities of Career Progress (Odds Ratios)

\begin{tabular}{|c|c|c|c|c|c|c|c|c|}
\hline \multirow[b]{3}{*}{ VARIABLE } & \multicolumn{4}{|c|}{ PROMOTIONS } & \multicolumn{4}{|c|}{ QUITS TO BETTER JOB } \\
\hline & \multicolumn{2}{|c|}{ Logit RE } & \multicolumn{2}{|c|}{ Logit FE } & \multicolumn{2}{|c|}{ Logit RE } & \multicolumn{2}{|c|}{ Logit FE } \\
\hline & $\underline{\text { Men }}$ & Women & $\underline{\text { Men }}$ & $\underline{\text { Women }}$ & $\underline{\text { Men }}$ & $\underline{\text { Women }}$ & Men & $\underline{\text { Women }}$ \\
\hline Train & $1.280^{* * *}$ & $1.326^{* * *}$ & 1.038 & $1.198^{* *}$ & 0.967 & $1.213^{* * *}$ & 1.074 & $1.249^{* *}$ \\
\hline Promoted (t-1) & $1.777^{* * *}$ & $1.655^{* * *}$ & & & $0.552^{* * *}$ & $0.615^{* * *}$ & $0.582^{* * *}$ & 0.777 \\
\hline Tenure (months) & 0.969 & $0.906^{* * *}$ & $1.146^{* * *}$ & $1.135^{* * *}$ & $0.824^{* * *}$ & $0.801^{* * *}$ & $0.799^{* * *}$ & $0.778^{* *}$ \\
\hline Tenure squared & 0.998 & 1.002 & $0.997^{* *}$ & $0.997^{*}$ & $1.003^{* *}$ & $1.003^{* *}$ & $1.010^{* * *}$ & 1.004 \\
\hline Experience (months) & 0.992 & 1.004 & 1.013 & 1.018 & $0.986^{*}$ & $0.980^{* * *}$ & $0.975^{*}$ & $0.961^{* *}$ \\
\hline Experience sq. & 1.000 & $0.999^{* *}$ & 1.000 & 0.999 & 1.000 & 1.000 & 1.000 & 1.001 \\
\hline Temporal Contract & $0.437^{* * *}$ & $0.393^{* * *}$ & $0.472^{*}$ & $0.545^{*}$ & 1.169 & 1.185 & 1.081 & 1.332 \\
\hline Fixed-Term Contract & $0.682^{*}$ & $0.619^{* *}$ & 1.012 & 0.866 & 1.138 & $1.419^{* *}$ & 1.189 & $2.213^{* * *}$ \\
\hline Part-time & $0.512^{* * *}$ & $0.563^{* * *}$ & 0.612 & 0.773 & $0.618^{* * *}$ & $0.819^{* * *}$ & 0.969 & 1.202 \\
\hline Overtime & $1.232^{* *}$ & $1.196^{* *}$ & $1.240^{*}$ & 0.945 & 0.892 & 1.012 & 0.921 & 0.892 \\
\hline Bonus & $1.186^{* * *}$ & $1.479^{* * *}$ & 1.045 & $1.566^{* *}$ & 0.965 & $0.797^{* * *}$ & $0.856^{*}$ & $0.771^{* *}$ \\
\hline Union Coverage & $1.411^{* * *}$ & $1.189^{*}$ & $1.409^{* *}$ & 1.264 & $0.750^{* * *}$ & $0.736^{* * *}$ & 0.814 & $0.666^{* *}$ \\
\hline Union Membership & $0.763^{* * *}$ & $0.836^{*}$ & 0.860 & 0.806 & $0.785^{* *}$ & $0.780^{* *}$ & 0.817 & 1.872 \\
\hline Higher Degree & $2.149^{* * *}$ & $1.887^{* * *}$ & & & 0.971 & 1.335 & & \\
\hline First Degree & $2.449^{* * *}$ & $1.792^{* * *}$ & & & $1.217^{*}$ & $1.313^{* * *}$ & & \\
\hline A- Level & $1.910^{* * *}$ & $1.603^{* * *}$ & & & 1.176 & $1.409^{* * *}$ & & \\
\hline O- Level & $1.823^{* * *}$ & $1.397^{* * *}$ & & & 1.138 & $1.188^{*}$ & & \\
\hline CSE & $1.406^{* *}$ & 1.288 & & & $1.256^{*}$ & 1.230 & & \\
\hline Other Controls & & & & & & & & \\
\hline Mngr. Resp. Dummies & Yes & Yes & Yes & Yes & Yes & Yes & Yes & Yes \\
\hline Firm Size Dummies & Yes & Yes & Yes & Yes & Yes & Yes & Yes & Yes \\
\hline Industrial Dummies & Yes & Yes & Yes & Yes & Yes & Yes & Yes & Yes \\
\hline Regional Dummies & Yes & Yes & Yes & Yes & Yes & Yes & Yes & Yes \\
\hline Year Dummies & Yes & Yes & Yes & Yes & Yes & Yes & Yes & Yes \\
\hline Employer Match & & & Yes & Yes & & & Yes & Yes \\
\hline Number of Obs. & 19146 & 18002 & 5583 & 4532 & 19146 & 18002 & 5197 & 4762 \\
\hline Model $\chi^{2}$ & $600.2^{* * *}$ & $692.9^{* * *}$ & $183.4^{* * * *}$ & $155.5^{* * *}$ & $621.6^{* * *}$ & $498.0^{* * * *}$ & $607.6^{* * *}$ & $590.8^{* * * *}$ \\
\hline Rho & $0.081^{* * * *}$ & 0.000 & & & $0.121^{* * *}$ & $0.095^{* * * *}$ & & \\
\hline
\end{tabular}

* Significant at $10 \%,{ }^{* *}$ Significant at 5\%. ${ }^{* * *}$ Significant at $1 \%$. 
Table 2: Effect of Last two years training incidence and intensity on Career Progress (Odds Ratios)

\begin{tabular}{|c|c|c|c|c|c|c|c|c|}
\hline \multirow[b]{3}{*}{ VARIABLE } & \multicolumn{4}{|c|}{ PROMOTIONS } & \multicolumn{4}{|c|}{ QUITS TO BETTER JOB } \\
\hline & \multicolumn{2}{|c|}{ Logit RE } & \multicolumn{2}{|c|}{ Logit FE } & \multicolumn{2}{|c|}{ Logit RE } & \multicolumn{2}{|c|}{ Logit FE } \\
\hline & Men & Women & $\underline{\text { Men }}$ & $\underline{\text { Women }}$ & $\underline{\text { Men }}$ & $\underline{\text { Women }}$ & $\underline{\text { Men }}$ & Women \\
\hline Incidence last year & $1.280^{* * * *}$ & $1.326^{* * *}$ & 1.038 & $1.198^{* *}$ & 0.967 & $1.213^{* * *}$ & 1.074 & $1.249^{* *}$ \\
\hline Days last year & 1.001 & $1.003^{* *}$ & 0.999 & $1.004^{* *}$ & 0.998 & 1.001 & $0.996^{* *}$ & 1.001 \\
\hline Incidence last 2 years & $1.388^{* * *}$ & $1.432^{* *}$ & 1.106 & $1.260^{* *}$ & $0.881^{*}$ & 1.088 & 0.927 & 1.114 \\
\hline Days last 2 years & $1.002^{* *}$ & $1.002^{* * *}$ & 1.000 & $1.002^{*}$ & 0.999 & 1.001 & 0.999 & 1.002 \\
\hline
\end{tabular}

All regressions include the same control variables of the analogous regressions summarised in Table 1. ${ }^{*}$ Significant at $10 \% .{ }^{* *}$ Significant at $5 \% .{ }^{* * *}$ Significant at $1 \%$. 
Table 3: Effect of training incidence and promotion on wages. Fixed-Effects Log-Wage Regressions.

\begin{tabular}{|c|c|c|c|c|c|c|c|c|}
\hline \multirow{2}{*}{ VARIABLE } & \multicolumn{2}{|c|}{ Model I } & \multicolumn{2}{|c|}{ Model II } & \multicolumn{2}{|c|}{ Model III } & \multicolumn{2}{|c|}{ Model IV } \\
\hline & Men & Women & Men & Women & Men & Women & Men & Women \\
\hline $\begin{array}{l}\text { Training Incidence } \\
\text { w/ current employer } \\
\text { (cumulated events) }\end{array}$ & $\begin{array}{l}0.016^{* * *} \\
(0.002)\end{array}$ & $\begin{array}{l}0.019^{* *} \\
(0.003)\end{array}$ & & & $\begin{array}{l}0.014^{* * *} \\
(0.002)\end{array}$ & $\begin{array}{l}0.018^{* * *} \\
(0.003)\end{array}$ & $\begin{array}{l}0.013^{* * *} \\
(0.003)\end{array}$ & $\begin{array}{l}0.018^{* * *} \\
(0.003)\end{array}$ \\
\hline $\begin{array}{l}\text { Training Incidence } \\
\text { w/ former employers } \\
\text { (cumulated events) }\end{array}$ & $\begin{array}{l}0.004 \\
(0.005)\end{array}$ & $\begin{array}{l}0.019^{* *} \\
(0.001)\end{array}$ & & & $\begin{array}{l}0.006 \\
(0.006)\end{array}$ & $\begin{array}{l}0.021^{* * *} \\
(0.007)\end{array}$ & $\begin{array}{l}0.007 \\
(0.006)\end{array}$ & $\begin{array}{l}0.021^{* * *} \\
(0.007)\end{array}$ \\
\hline $\begin{array}{l}\text { Promotion w/ current } \\
\text { employer }\end{array}$ & & & $\begin{array}{l}0.070^{* * *} \\
(0.009)\end{array}$ & $\begin{array}{l}0.075^{* * *} \\
(0.010)\end{array}$ & $\begin{array}{l}0.067^{* * *} \\
(0.009)\end{array}$ & $\begin{array}{l}0.069^{* * *} \\
(0.010)\end{array}$ & $\begin{array}{l}0.054^{* * *} \\
(0.012)\end{array}$ & $\begin{array}{l}0.070^{* * *} \\
(0.015)\end{array}$ \\
\hline $\begin{array}{l}\text { Promotion*Training } \\
\text { w/ current employer }\end{array}$ & & & & & & & $\begin{array}{l}0.009^{*} \\
(0.006)\end{array}$ & $\begin{array}{c}-0.001 \\
(0.006)\end{array}$ \\
\hline $\begin{array}{l}\text { Promotion*Training } \\
\text { w/ former employer }\end{array}$ & & & & & & & $\begin{array}{l}-0.017 \\
(0.034)\end{array}$ & $\begin{array}{l}0.004 \\
(0.034)\end{array}$ \\
\hline $\begin{array}{l}\text { Quit for a Better } \\
\text { Job }\end{array}$ & $\begin{array}{l}0.011 \\
(0.009)\end{array}$ & $\begin{array}{l}0.016 \\
(0.010)\end{array}$ & $\begin{array}{l}0.019^{* *} \\
(0.009)\end{array}$ & $\begin{array}{l}0.024^{* *} \\
(0.010)\end{array}$ & $\begin{array}{l}0.020^{* *} \\
(0.009)\end{array}$ & $\begin{array}{l}0.022^{* *} \\
(0.010)\end{array}$ & $\begin{array}{l}0.020^{* *} \\
(0.009)\end{array}$ & $\begin{array}{l}0.022^{* *} \\
(0.011)\end{array}$ \\
\hline Tenure (years) & $\begin{array}{l}0.001 \\
(0.001)\end{array}$ & $\begin{array}{l}-0.005^{* * *} \\
(0.001)\end{array}$ & $\begin{array}{l}0.004^{* * *} \\
(0.001)\end{array}$ & $\begin{array}{r}-0.001 \\
(0.002)\end{array}$ & $\begin{array}{l}0.003^{* *} \\
(0.001)\end{array}$ & $\begin{array}{c}-0.002 \\
(0.002)\end{array}$ & $\begin{array}{l}0.003^{* *} \\
(0.001)\end{array}$ & $\begin{array}{r}-0.002 \\
(0.002)\end{array}$ \\
\hline Tenure sq. $\times 10^{3}$ & $\begin{array}{l}-0.201^{* * *} \\
(0.045)\end{array}$ & $\begin{array}{r}-0.093 \\
(0.063)\end{array}$ & $\begin{array}{l}-0.291^{* *} \\
(0.047)\end{array}$ & $\begin{array}{l}-0.199^{* * *} \\
(0.064)\end{array}$ & $\begin{array}{l}-0.269^{* * *} \\
(0.047)\end{array}$ & $\begin{array}{l}-0.184^{* * *} \\
(0.064)\end{array}$ & $\begin{array}{l}-0.270^{* * *} \\
(0.047)\end{array}$ & $\begin{array}{c}-0.183^{* * *} \\
(0.064)\end{array}$ \\
\hline $\begin{array}{l}\text { Previous } \\
\text { Experience (years) }\end{array}$ & $\begin{array}{l}-0.004^{* * *} \\
(0.000)\end{array}$ & $\begin{array}{l}-0.004^{* * *} \\
(0.001)\end{array}$ & $\begin{array}{l}-0.004^{* * *} \\
(0.000)\end{array}$ & $\begin{array}{c}-0.004^{* * *} \\
(0.001)\end{array}$ & $\begin{array}{c}-0.004^{* * *} \\
(0.000)\end{array}$ & $\begin{array}{l}-0.004^{* * *} \\
(0.001)\end{array}$ & $\begin{array}{l}-0.004^{* * *} \\
(0.001)\end{array}$ & $\begin{array}{c}-0.004^{* * *} \\
(0.001)\end{array}$ \\
\hline $\begin{array}{l}\text { Previous } \\
\text { Experience sq. } \times 10^{3} \\
\text { Other Controls }\end{array}$ & $\begin{array}{l}-0.038^{* * *} \\
(0.011)\end{array}$ & $\begin{array}{c}-0.021 \\
(0.014)\end{array}$ & $\begin{array}{l}-0.034^{* * *} \\
(0.011)\end{array}$ & $\begin{array}{r}-0.025^{*} \\
(0.014)\end{array}$ & $\begin{array}{l}-0.040^{* * *} \\
(0.011)\end{array}$ & $\begin{array}{r}-0.022 \\
(0.014)\end{array}$ & $\begin{array}{l}-0.040^{* * *} \\
(0.011)\end{array}$ & $\begin{array}{r}-0.022 \\
(0.014)\end{array}$ \\
\hline $\begin{array}{l}\text { Job Characteristics } \\
\text { Dummies }\end{array}$ & Yes & Yes & Yes & Yes & Yes & Yes & Yes & Yes \\
\hline Firm Size Dummies & Yes & Yes & Yes & Yes & Yes & Yes & Yes & Yes \\
\hline Industrial Dummies & Yes & Yes & Yes & Yes & Yes & Yes & Yes & Yes \\
\hline Regional Dummies & Yes & Yes & Yes & Yes & Yes & Yes & Yes & Yes \\
\hline Year Dummies & Yes & Yes & Yes & Yes & Yes & Yes & Yes & Yes \\
\hline Employer Match & & & Yes & Yes & & & Yes & Yes \\
\hline $\mathrm{R}$-square & 0.031 & 0.074 & 0.038 & 0.078 & 0.040 & 0.078 & 0.040 & 0.078 \\
\hline
\end{tabular}

* Significant at $10 \%$. ${ }^{* * *}$ Significant at $5 \%$. ${ }^{* * * *}$ Significant at $1 \%$. 
Table 4: Effect on wages of training intensity and career moves Fixed-Effects Log-Wage Regressions.

\begin{tabular}{|c|c|c|c|c|c|c|c|c|}
\hline \multirow{2}{*}{ VARIABLE } & \multicolumn{2}{|c|}{ Model I } & \multicolumn{2}{|c|}{ Model II } & \multicolumn{2}{|c|}{ Model III } & \multicolumn{2}{|c|}{ Model IV } \\
\hline & Men & $\underline{\text { Women }}$ & Men & $\underline{\text { Women }}$ & Men & $\underline{\text { Women }}$ & Men & $\underline{\text { Women }}$ \\
\hline $\begin{array}{l}\text { Training Intensity } \\
\text { w/ current employer } \\
\text { (cumulated days) }\end{array}$ & $\begin{array}{l}0.00019^{* * *} \\
(0.00006)\end{array}$ & $\begin{array}{l}0.00018^{* *} \\
(0.00007)\end{array}$ & & & $\begin{array}{l}0.00017^{* *} \\
(0.00006)\end{array}$ & $\begin{array}{l}0.00016^{* *} \\
(0.00006)\end{array}$ & $\begin{array}{l}0.00017^{* *} \\
(0.00006)\end{array}$ & $\begin{array}{l}0.00016^{*} \\
(0.00007)\end{array}$ \\
\hline $\begin{array}{l}\text { Training Intensity } \\
\text { w/ former employers } \\
\text { (cumulated days) }\end{array}$ & $\begin{array}{l}0.00031^{* *} \\
(0.00010)\end{array}$ & $\begin{array}{l}0.00030^{* * *} \\
(0.00015)\end{array}$ & & & $\begin{array}{l}0.00031^{* * * *} \\
(0.00010)\end{array}$ & $\begin{array}{l}0.00030^{* *} \\
(0.00015)\end{array}$ & $\begin{array}{l}0.00032^{* *} \\
(0.00006)\end{array}$ & $\begin{array}{l}0.00033^{* *} \\
(0.00015)\end{array}$ \\
\hline $\begin{array}{l}\text { Promotion w/ current } \\
\text { employer }\end{array}$ & & & $\begin{array}{l}0.0704^{* * * *} \\
(0.0086)\end{array}$ & $\begin{array}{l}0.0751^{* * *} \\
(0.0101)\end{array}$ & $\begin{array}{l}0.0714^{* *} \\
(0.0092)\end{array}$ & $\begin{array}{l}0.0740^{* *} \\
(0.0109)\end{array}$ & $\begin{array}{l}0.0720^{* * *} \\
(0.0095)\end{array}$ & $\begin{array}{l}0.0743^{* *} \\
(0.0116)\end{array}$ \\
\hline $\begin{array}{l}\text { Promotion*Training } \\
\text { w/ current employer }\end{array}$ & & & & & & & $\begin{array}{l}0.00001 \\
(0.00009)\end{array}$ & $\begin{array}{l}0.00002 \\
(0.00012)\end{array}$ \\
\hline $\begin{array}{l}\text { Promotion*Training } \\
\text { w/ former employer }\end{array}$ & & & & & & & $\begin{array}{l}-0.00047 \\
(0.00062)\end{array}$ & $\begin{array}{r}-0.00077 \\
(0.00063)\end{array}$ \\
\hline
\end{tabular}

All regressions include the same control variables of the analogous regressions summarised in Table 3.

$*$ Significant at $10 \%$. **Significant at $5 \%$. ***Significant at $1 \%$.

Table 5: Effect of last year General and Specific training incidence on Career Progress (Odds Ratios)

\begin{tabular}{|c|c|c|c|c|c|c|c|c|}
\hline \multirow{3}{*}{ VARIABLE } & \multicolumn{4}{|c|}{ PROMOTIONS } & \multicolumn{4}{|c|}{ OUITS TO BETTER JOB } \\
\hline & \multicolumn{2}{|c|}{ Logit RE } & \multicolumn{2}{|c|}{ Logit FE } & \multicolumn{2}{|c|}{ Logit RE } & \multicolumn{2}{|c|}{ Logit FE } \\
\hline & Men & Women & $\underline{\text { Men }}$ & Women & $\underline{\text { Men }}$ & Women & Men & Women \\
\hline $\begin{array}{l}\text { "General" Training } \\
\text { Incidence last year }\end{array}$ & $1.275^{* * *}$ & $1.287^{* * * *}$ & 0.973 & 1.145 & 0.948 & $1.206^{* *}$ & 0.972 & $1.260^{* *}$ \\
\hline $\begin{array}{l}\text { "Specific" Training } \\
\text { Incidence last year }\end{array}$ & 1.046 & $1.327^{* * *}$ & 0.961 & $1.352^{* *}$ & 0.970 & 1.115 & 1.121 & 1.167 \\
\hline
\end{tabular}

All regressions include the same control variables of the analogous regressions summarised in Table 1.

$*$ Significant at $10 \%$. $* *$ Significant at $5 \%$. ***Significant at $1 \%$. 
Table 6: General and Specific training, Quits and Wages. Fixed-Effects Log-Wage Regressions.

\begin{tabular}{|c|c|c|c|c|c|c|}
\hline \multirow{2}{*}{ VARIABLE } & \multicolumn{2}{|c|}{ Model I } & \multicolumn{2}{|c|}{ Model II } & \multicolumn{2}{|c|}{ Model III } \\
\hline & $\underline{\text { Men }}$ & $\underline{\text { Women }}$ & $\underline{\text { Men }}$ & Women & Men & $\underline{\text { Women }}$ \\
\hline $\begin{array}{l}\text { "General" } \\
\text { Training Incidence with } \\
\text { current employer } \\
\text { (cumulated events) }\end{array}$ & $0.0131^{* * *}$ & $0.0226^{* * *}$ & $0.0111^{* * *}$ & $0.0218^{* * *}$ & $0.0102^{* * *}$ & $0.0218^{* * *}$ \\
\hline $\begin{array}{l}\text { "General" } \\
\text { Training Incidence with } \\
\text { former employers } \\
\text { (cumulated events) }\end{array}$ & 0.0060 & $0.0203^{* *}$ & 0.0080 & $0.0223^{* *}$ & 0.0086 & $0.0232^{* * *}$ \\
\hline $\begin{array}{l}\text { "Specific" } \\
\text { Training Incidence with } \\
\text { current employer } \\
\text { (cumulated events) }\end{array}$ & $0.0209^{* * *}$ & 0.0094 & $0.0217^{* * *}$ & 0.0083 & $0.0211^{* * *}$ & 0.0088 \\
\hline $\begin{array}{l}\text { "Specific" } \\
\text { Training Incidence w/ } \\
\text { former employer } \\
\text { (cumulated events) }\end{array}$ & -0.0187 & 0.0109 & -0.0153 & 0.0111 & -0.0165 & 0.0088 \\
\hline $\begin{array}{l}\text { Promotion w/ current } \\
\text { employer }\end{array}$ & & & $0.0679^{* * * *}$ & $0.0677^{* * *}$ & $0.0571^{* * *}$ & $0.0699^{* * * *}$ \\
\hline $\begin{array}{l}\text { Promotion*General } \\
\text { Training with current } \\
\text { employer }\end{array}$ & & & & & 0.0074 & -0.0005 \\
\hline $\begin{array}{l}\text { Promotion*Specific } \\
\text { Training with current } \\
\text { employer }\end{array}$ & & & & & 0.0084 & -0.0061 \\
\hline Quit for a Better Job & 0.0095 & 0.0170 & $0.0181^{*}$ & $0.0229^{* *}$ & $0.0183^{*}$ & $0.0230^{* *}$ \\
\hline
\end{tabular}

All regressions include the same control variables of the analogous regressions summarised in Table 3. ${ }^{*}$ Significant at $10 \% .{ }^{* *}$ Significant at $5 \% .{ }^{* * *}$ Significant at $1 \%$. 
Table 7: Effect of Last year Training Incidence on the Probabilities of Career Progress (Odds Ratios) by Age Groups. Independent Variable: Incidence Last year

\begin{tabular}{|c|c|c|c|c|c|c|c|c|}
\hline \multirow{3}{*}{ AGE GROUP } & \multicolumn{4}{|c|}{ PROMOTIONS } & \multicolumn{4}{|c|}{ OUITS TO BETTER JO } \\
\hline & \multicolumn{2}{|c|}{ Logit RE } & \multicolumn{2}{|c|}{ Logit FE } & \multicolumn{2}{|c|}{ Logit RE } & \multicolumn{2}{|c|}{ Logit FE } \\
\hline & $\underline{\text { Men }}$ & $\underline{\text { Women }}$ & $\underline{\text { Men }}$ & Women & $\underline{\text { Men }}$ & $\underline{\text { Women }}$ & $\underline{\text { Men }}$ & Women \\
\hline Twenties & $1.407^{* * * *}$ & $1.468^{* * *}$ & 1.018 & $1.759^{* * *}$ & 0.929 & $1.301^{* *}$ & 0.946 & $1.441^{* *}$ \\
\hline Thirties & $1.345^{* * *}$ & $1.416^{* * *}$ & 1.176 & 1.185 & 0.944 & 1.144 & 1.129 & 1.242 \\
\hline Forties & 0.970 & 0.998 & $0.659^{* *}$ & 0.943 & 1.207 & 1.289 & 1.340 & 1.089 \\
\hline Older & $1.506^{* *}$ & 1.390 & $1.634^{* *}$ & 0.977 & 0.967 & 0.907 & $2.398^{* * *}$ & 0.878 \\
\hline
\end{tabular}

All regressions include the same control variables of the analogous regressions summarised in Table 1. "Significant at $10 \% .{ }^{* *}$ Significant at $5 \% .{ }^{* * *}$ Significant at $1 \%$.

Table 8: Training, Promotion, Quits and Wages: Age Groups. Fixed-Effects Log-Wage Regressions.

\begin{tabular}{|c|c|c|c|c|c|c|c|c|}
\hline \multirow{2}{*}{ VARIABLE } & \multicolumn{2}{|c|}{ Twenties } & \multicolumn{2}{|c|}{ Thirties } & \multicolumn{2}{|c|}{ Forties } & \multicolumn{2}{|c|}{ Older } \\
\hline & Men & $\underline{\text { Women }}$ & Men & $\underline{\text { Women }}$ & Men & Women & Men & $\underline{\text { Women }}$ \\
\hline $\begin{array}{l}\text { Training Incidence } \\
\text { w/ current employer } \\
\text { (cumulated events) }\end{array}$ & $\begin{array}{l}0.0253^{* * *} \\
(0.00834)\end{array}$ & $\begin{array}{l}0.0326^{* * *} \\
(0.00833)\end{array}$ & $\begin{array}{l}0.0062 \\
(0.00416)\end{array}$ & $\begin{array}{c}0.0092^{*} \\
(0.00513)\end{array}$ & $\begin{array}{l}0.0022 \\
(0.00414)\end{array}$ & $\begin{array}{l}0.0181^{* * *} \\
(0.00535)\end{array}$ & $\begin{array}{l}0.0077^{*} \\
(0.00460)\end{array}$ & $\begin{array}{l}0.0004 \\
(0.00514)\end{array}$ \\
\hline $\begin{array}{l}\text { Training Incidence } \\
\text { w/ former employers } \\
\text { (cumulated events) }\end{array}$ & $\begin{array}{l}0.0319^{* *} \\
(0.01473)\end{array}$ & $\begin{array}{l}0.0234 \\
(0.01603)\end{array}$ & $\begin{array}{l}-0.0085 \\
(0.00813)\end{array}$ & $\begin{array}{l}0.0088 \\
(0.01070)\end{array}$ & $\begin{array}{l}-0.0122 \\
(0.01019)\end{array}$ & $\begin{array}{l}0.0344^{* * * *} \\
(0.01210)\end{array}$ & $\begin{array}{r}-0.0054 \\
(0.01603)\end{array}$ & $\begin{array}{r}-0.0107 \\
(0.01674)\end{array}$ \\
\hline $\begin{array}{l}\text { Promotion w/ current } \\
\text { employer }\end{array}$ & $\begin{array}{l}0.0917^{* * *} \\
(0.02258)\end{array}$ & $\begin{array}{l}0.0869^{* * *} \\
(0.00834)\end{array}$ & $\begin{array}{l}0.0627^{* * *} \\
(0.01353)\end{array}$ & $\begin{array}{l}0.0582^{* * *} \\
(0.01650)\end{array}$ & $\begin{array}{l}0.0364^{* *} \\
(0.01510)\end{array}$ & $\begin{array}{l}0.0383^{*} \\
(0.02113)\end{array}$ & $\begin{array}{l}0.0278 \\
(0.02027)\end{array}$ & $\begin{array}{l}0.0740^{* * *} \\
(0.02413)\end{array}$ \\
\hline $\begin{array}{l}\text { Quit for a Better } \\
\text { Job }\end{array}$ & $\begin{array}{l}0.0533^{* * *} \\
(0.02034)\end{array}$ & $\begin{array}{l}0.0550^{* *} \\
(0.02251)\end{array}$ & $\begin{array}{l}0.0206 \\
(0.01441)\end{array}$ & $\begin{array}{l}0.0097 \\
(0.01723)\end{array}$ & $\begin{array}{l}0.0227 \\
(0.01844)\end{array}$ & $\begin{array}{l}0.0087 \\
(0.02136)\end{array}$ & $\begin{array}{l}-0.0534^{* *} \\
(0.02549)\end{array}$ & $\begin{array}{l}0.0423^{*} \\
(0.02530)\end{array}$ \\
\hline
\end{tabular}

All regressions include the same control variables of the analogous regressions summarised in Table 3 . "Significant at $10 \%$. ${ }^{* *}$ Significant at $5 \% .{ }^{* * *}$ Significant at $1 \%$. 
Table 9: Effect of Last year Training Incidence on the Probabilities of Internal Promotion (Odds Ratios) by Seniority Groups (quartiles of the distribution) .Random effects estimates.

\begin{tabular}{|c|c|c|c|c|c|c|c|c|}
\hline \multirow{2}{*}{$\underline{\text { VARIABLE }}$} & \multicolumn{2}{|c|}{$<28$ months } & \multicolumn{2}{|c|}{$28-73$ months } & \multicolumn{2}{|c|}{73 - 159 months } & \multicolumn{2}{|c|}{$>159$ months } \\
\hline & Men & Women & Men & Women & Men & Women & Men & Women \\
\hline Train & $1.290^{*}$ & $1.297^{*}$ & $1.251^{* *}$ & $1.432^{* *}$ & $1.373^{* * *}$ & $1.314^{* *}$ & $1.363^{* *}$ & $1.388^{*}$ \\
\hline Promoted (t-1) & $1.982^{* * *}$ & $1.892^{* * *}$ & $1.994^{* * *}$ & $1.744^{* * * *}$ & $1.466^{* *}$ & $1.794^{* * *}$ & $3.059^{* * * *}$ & $2.520^{* * * *}$ \\
\hline Overtime & 1.179 & $1.019^{* * *}$ & $1.231^{*}$ & $1.266^{* *}$ & $1.357^{* *}$ & $1.403^{* *}$ & 1.149 & 1.159 \\
\hline $\begin{array}{l}\text { Effect of seniority } \\
\text { group }\end{array}$ & \multicolumn{2}{|c|}{ Baseline } & 1.072 & 0.824 & 0.903 & $0.678^{* *}$ & $0.678^{* *}$ & $0.580^{* * *}$ \\
\hline
\end{tabular}

All regressions include the same control variables of the analogous regressions summarised in Table 1.

"Significant at $10 \% .{ }^{* *}$ Significant at $5 \% .{ }^{* * *}$ Significant at $1 \%$.

Table 10: Training, Promotion, Quits and Wages: Seniority Groups. Fixed-Effects Log-Wage Regressions.

\begin{tabular}{|c|c|c|c|c|c|c|c|c|}
\hline \multirow{2}{*}{ VARIABLE } & \multicolumn{2}{|c|}{$<28$ months } & \multicolumn{2}{|c|}{$28-73$ months } & \multicolumn{2}{|c|}{73 - 159 months } & \multicolumn{2}{|c|}{$>159$ months } \\
\hline & Men & Women & Men & Women & Men & Women & Men & Women \\
\hline $\begin{array}{l}\text { Training Incidence } \\
\text { w/ current employer } \\
\text { (cumulated events) }\end{array}$ & $\begin{array}{l}0.0272^{* * *} \\
(0.00799)\end{array}$ & $\begin{array}{l}0.0018 \\
(0.00790)\end{array}$ & $\begin{array}{l}0.0199^{* * *} \\
(0.00486)\end{array}$ & $\begin{array}{l}0.0225^{* * *} \\
(0.00452)\end{array}$ & $\begin{array}{l}0.0151^{* * *} \\
(0.00397)\end{array}$ & $\begin{array}{l}0.0104^{* * *} \\
(0.00387)\end{array}$ & $\begin{array}{l}0.0141^{* *} \\
(0.00473)\end{array}$ & $\begin{array}{l}0.0121^{* * *} \\
(0.00344)\end{array}$ \\
\hline $\begin{array}{l}\text { Training Incidence } \\
\text { w/ former employers } \\
\text { (cumulated events) }\end{array}$ & $\begin{array}{l}0.0236^{* * *} \\
(0.00959)\end{array}$ & $\begin{array}{l}0.0134 \\
(0.00827)\end{array}$ & $\begin{array}{l}0.0298^{* *} \\
(0.01213)\end{array}$ & $\begin{array}{l}0.0102 \\
(0.01044)\end{array}$ & $\begin{array}{l}-0.0068 \\
(0.01413)\end{array}$ & $\begin{array}{c}-0.0190^{*} \\
(0.01263)\end{array}$ & $\begin{array}{c}-0.0514 \\
(0.03412)\end{array}$ & $\begin{array}{r}-0.0316 \\
(0.02112)\end{array}$ \\
\hline $\begin{array}{l}\text { Promotion w/ current } \\
\text { employer }\end{array}$ & $\begin{array}{l}0.0380 \\
(0.02607)\end{array}$ & $\begin{array}{l}0.1178^{* * *} \\
(0.02326)\end{array}$ & $\begin{array}{l}0.0861^{* * *} \\
(0.01649)\end{array}$ & $\begin{array}{l}0.0474^{* * * *} \\
(0.01508)\end{array}$ & $\begin{array}{l}0.0420^{* *} \\
(0.01716)\end{array}$ & $\begin{array}{l}0.0567^{* *} \\
(0.01485)\end{array}$ & $\begin{array}{l}0.0813^{* * *} \\
(0.02309)\end{array}$ & $\begin{array}{l}0.0305^{* *} \\
(0.01549)\end{array}$ \\
\hline $\begin{array}{l}\text { Quit for a Better } \\
\text { Job }\end{array}$ & $\begin{array}{l}0.0207 \\
(0.01422)\end{array}$ & $\begin{array}{l}0.0451^{* * *} \\
(0.01307)\end{array}$ & & & & & & \\
\hline
\end{tabular}

All regressions include the same control variables of the analogous regressions summarised in Table 3. "Significant at $10 \%$. ${ }^{* *}$ Significant at $5 \% .{ }^{* * *}$ Significant at $1 \%$. 


\section{Appendix A: Theories about career paths}

\begin{tabular}{|c|c|c|c|c|}
\hline & $\begin{array}{l}\text { Correlation } \\
\text { training- promotion }\end{array}$ & Wage Growth & $\begin{array}{l}\text { Interaction in } \\
\text { wage growth }\end{array}$ & Other features \\
\hline $\begin{array}{l}\text { Human capital } \\
\text { accumulation and } \\
\text { Learning about } \\
\text { ability }\end{array}$ & Positive & $\begin{array}{l}\text { Higher after } \\
\text { promotion, especially } \\
\text { upon promotion }\end{array}$ & Positive & $\begin{array}{l}\text { Ambiguous effect } \\
\text { of seniority and } \\
\text { experience on } \\
\text { promotion }\end{array}$ \\
\hline $\begin{array}{l}\text { Incentives to invest } \\
\text { in Specific human } \\
\text { capital }\end{array}$ & $\begin{array}{l}\text { Positive (specific } \\
\text { human capital) }\end{array}$ & $\begin{array}{l}\text { Much higher upon } \\
\text { promotion }\end{array}$ & $\begin{array}{l}\text { Positive (specific } \\
\text { human capital, } \\
\text { returns to training } \\
\text { are otherwise nil) }\end{array}$ & $\begin{array}{l}\text { - Positive effect of } \\
\text { seniority on } \\
\text { promotion } \\
\text { - Lower returns to } \\
\text { seniority for not } \\
\text { promoted. }\end{array}$ \\
\hline Incentives to effort & No prediction & $\begin{array}{l}\text { Much higher upon } \\
\text { promotion }\end{array}$ & No prediction & $\begin{array}{l}\text { - Positive effect of } \\
\text { measures of effort } \\
\text { on promotion } \\
\text { - Effect of } \\
\text { measures of effort } \\
\text { on wage decrease } \\
\text { as we control for } \\
\text { promotions }\end{array}$ \\
\hline Asymmetric info & Positive & $\begin{array}{l}\text { Much higher upon } \\
\text { promotion }\end{array}$ & Negative & $\begin{array}{l}\text { Stronger effects } \\
\text { for younger and } \\
\text { "more uncertain" } \\
\text { groups. }\end{array}$ \\
\hline
\end{tabular}

\begin{tabular}{|l|l|l|l|}
\hline $\begin{array}{l}\text { Predictions of Gender } \\
\text { differences theories }\end{array}$ & $\begin{array}{l}\text { Correlation training- } \\
\text { promotion and their } \\
\text { interaction in wage growth }\end{array}$ & $\begin{array}{l}\text { Gender differences } \\
\text { in promotion rates }\end{array}$ & $\begin{array}{l}\text { Gender differences in wage } \\
\text { growth }\end{array}$ \\
\hline Lazear-Rosen & $\begin{array}{l}\text { Same effects of incentives } \\
\text { theories. Similar effects for } \\
\text { men and women }\end{array}$ & $\begin{array}{l}\text { Women get less } \\
\text { promotions }\end{array}$ & $\begin{array}{l}\text { Promoted females earn } \\
\text { more than promoted males }\end{array}$ \\
\hline Booth/Francesconi/Frank & & $\begin{array}{l}\text { Women get same } \\
\text { or more } \\
\text { promotions }\end{array}$ & $\begin{array}{l}\text { Promoted females earn } \\
\text { more than promoted males }\end{array}$ \\
\hline
\end{tabular}




\section{Appendix B: Key Questions from the BHPS}

\section{Question J9}

Can you look at this card please and tell me which of the following descriptions comes closest to what you were doing immediately before then (the job change)?

- Doing a different job for the same employer

- Working for a different employer

- In paid employment (not self employed)

- Working for myself (self-employed)

- Unemployed/looking for work

- Retired from paid work altogether

- On maternity leave

- Looking after a family or home

- In full-time education/student

- Long term sick or disabled

- On a government training scheme

- Something else (please give details)

\section{Question J21}

Would you look at this card please and tell me which of the following statements on the card best describes why you stopped doing that job?

- I was promoted

- I left for a better job

- I was made redundant

- I was dismissed/sacked

- It was a temporary job which ended

- I took retirement

- I gave up work for health reasons

- I left to have a baby

- I left to look after children/home

- I left to look after another person (not children)

- I left for another reason (please give details) 


\section{Appendix C: Descriptive Statistics of the most relevant variables}

\begin{tabular}{|c|c|c|c|}
\hline$\underline{\text { VARIABLE }}$ & $\begin{array}{c}\text { Men } \\
\text { (standard deviation) }\end{array}$ & $\begin{array}{c}\text { Women } \\
\text { (standard deviation) }\end{array}$ & $\begin{array}{c}\text { Difference } \\
\text { (standard error) }\end{array}$ \\
\hline $\mathrm{N}$ & 19140 & 18000 & \\
\hline Promotion Receipt & $\begin{array}{c}0.0797 \\
(0.2708)\end{array}$ & $\begin{array}{c}0.0638 \\
(0.2444)\end{array}$ & $\begin{array}{l}0.0159^{\text {*** }} \\
(0.0027)\end{array}$ \\
\hline Quit for a Better Job & $\begin{array}{c}0.0892 \\
(0.2850)\end{array}$ & $\begin{array}{c}0.0855 \\
(0.2780)\end{array}$ & $\begin{array}{l}0.0037 \\
(0.0029)\end{array}$ \\
\hline Training Incidence & $\begin{array}{l}0.3408 \\
(0.4740)\end{array}$ & $\begin{array}{c}0.3199 \\
(0.4664)\end{array}$ & $\begin{array}{l}0.0209^{* * *} \\
(0.0049)\end{array}$ \\
\hline $\begin{array}{l}\text { General Training } \\
\text { Incidence }\end{array}$ & $\begin{array}{c}0.2754 \\
(0.4467)\end{array}$ & $\begin{array}{l}0.2616 \\
(0.4395)\end{array}$ & $\begin{array}{l}0.0138^{* * *} \\
(0.0046)\end{array}$ \\
\hline $\begin{array}{l}\text { Specific Training } \\
\text { Incidence }\end{array}$ & $\begin{array}{l}0.0720 \\
(0.2585)\end{array}$ & $\begin{array}{l}0.0640 \\
(0.2448)\end{array}$ & $\begin{array}{l}0.008^{* * *} \\
(0.0026)\end{array}$ \\
\hline Training Days & $\begin{array}{l}5.7279 \\
(23.725)\end{array}$ & $\begin{array}{l}5.6092 \\
(25.817)\end{array}$ & $\begin{array}{c}0.1184 \\
(02631)\end{array}$ \\
\hline Age & $\begin{array}{c}36.196 \\
(11.888)\end{array}$ & $\begin{array}{c}36.022 \\
(11.862)\end{array}$ & $\begin{array}{c}0.1718 \\
(0.1233)\end{array}$ \\
\hline Years of Tenure & $\begin{array}{c}4.6012 \\
(6.0316)\end{array}$ & $\begin{array}{c}4.0390 \\
(5.0361)\end{array}$ & $\begin{array}{l}0.5618^{* * *} \\
(0.0578)\end{array}$ \\
\hline Job Market Experience & $\begin{array}{c}9.5474 \\
(13.489)\end{array}$ & $\begin{array}{l}9.7126 \\
(13.408)\end{array}$ & $\begin{array}{r}-0.183 \\
(0.1396)\end{array}$ \\
\hline Temporary & $\begin{array}{l}0.0376 \\
(0.1903)\end{array}$ & $\begin{array}{c}0.0553 \\
(0.2287)\end{array}$ & $\begin{array}{l}-0.0177^{* * * *} \\
(0.0022)\end{array}$ \\
\hline Fixed-Term & $\begin{array}{c}0.0279 \\
(0.1647)\end{array}$ & $\begin{array}{c}0.0258 \\
(0.1585)\end{array}$ & $\begin{array}{l}0.0021 \\
(0.0017)\end{array}$ \\
\hline Part-time & $\begin{array}{c}0.0573 \\
(0.2324)\end{array}$ & $\begin{array}{l}0.3638 \\
(0.4811)\end{array}$ & $\begin{array}{l}-0.3064^{* * *} \\
(0.0039)\end{array}$ \\
\hline Manager & $\begin{array}{c}0.2500 \\
(0.4330)\end{array}$ & $\begin{array}{c}0.1469 \\
(0.3541)\end{array}$ & $\begin{array}{l}0.103^{* * *} \\
(0.0041)\end{array}$ \\
\hline Foreman & $\begin{array}{c}0.1637 \\
(0.3700)\end{array}$ & $\begin{array}{l}0.1615 \\
(0.3680)\end{array}$ & $\begin{array}{c}0.0022 \\
(0.0038)\end{array}$ \\
\hline Overtime & $\begin{array}{c}0.5854 \\
(0.4927)\end{array}$ & $\begin{array}{c}0.3843 \\
(0.4864)\end{array}$ & $\begin{array}{l}0.201^{* * *} \\
(0.0051)\end{array}$ \\
\hline Receiving Bonus & $\begin{array}{c}0.4049 \\
(0.4909)\end{array}$ & $\begin{array}{c}0.2900 \\
(0.4538)\end{array}$ & $\begin{array}{l}0.1148^{* * *} \\
(0.0049)\end{array}$ \\
\hline Union Coverage & $\begin{array}{c}0.4029 \\
(0.4905)\end{array}$ & $\begin{array}{c}0.3865 \\
(0.4870)\end{array}$ & $\begin{array}{l}0.0163^{* * *} \\
(0.0051)\end{array}$ \\
\hline Union Membership & $\begin{array}{c}0.2602 \\
(0.4388)\end{array}$ & $\begin{array}{c}0.2201 \\
(0.4143)\end{array}$ & $\begin{array}{l}0.0401^{* * *} \\
(0.0044)\end{array}$ \\
\hline Hourly Wage (£ of 1998) & $\begin{array}{c}8.7541 \\
(6.2439) \\
\end{array}$ & $\begin{array}{r}6.3717 \\
(5.2873) \\
\end{array}$ & $\begin{array}{l}2.382^{* * *} \\
(0.0605)\end{array}$ \\
\hline
\end{tabular}

